\title{
PREDICTING CUSTOMER LIFETIME VALUE FOR HYPERMARKET PRIVATE LABEL PRODUCTS
}

\author{
Hsin-Hui LIN ${ }^{1}$, Hsien-Ta LI ${ }^{2}$, Yi-Shun WANG ${ }^{3}$, \\ Timmy H. TSENG ${ }^{4}$, Ya-Ling KAO ${ }^{5}$, Min-Yi WU ${ }^{6}$ \\ ${ }^{1,6}$ National Taichung University of Science and Technology, Department \\ of Distribution Management, Taichung, 40401 Taiwan \\ ${ }^{2}$ National Cheng Kung University, Tainan, 70101 Taiwan \\ 3, ${ }^{4}$ National Changhua University of Education, Department of Information Management, \\ No. 2, Shi-da Road, Changhua, 50058 Taiwan \\ ${ }^{5}$ National Kaohsiung University of Applied Sciences, Kaohsiung, 807 Taiwan

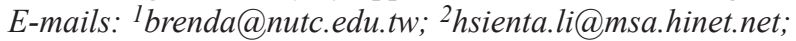 \\ 3yswang@cc.ncue.edu.tw (corresponding author); ${ }^{4}$ littlebeeballball@hotmail.com; \\ 5ylkao1211@gmail.com; ${ }^{6}$ ifleaveyou@gmail.com \\ Received 14 September 2016; accepted 16 March 2017
}

\begin{abstract}
This study develops a model to predict customer lifetime value for hypermarket private label products. It examines the relationships among store awareness, store image variables (i.e., service quality, price/value, convenience, and product quality), private label image, repurchase intention, and customer lifetime value and investigates the moderating role of image fit. The originality of this study lies in filling the gap of previous research on antecedents of private label customers' behavior by considering store awareness, image fit, and customer lifetime value. Partial least squares structural equation modeling was used to analyze data. The results indicate the following. Store image variables (except product quality) and store awareness affect repurchase intention directly or indirectly through private label image. Image fit moderates the relationships between store image variables (except product quality) and private label image. Private label image facilitates customer lifetime value. This study provides several theoretical and practical implications for hypermarket private label product developments.
\end{abstract}

Keywords: private label product, hypermarket, repurchase intention, customer lifetime value, store awareness, store image, image fit.

JEL Classification: M31.

\section{Introduction}

Private label products refer to products branded by distributers (Bodur et al. 2016). Researchers have used a set of terms to describe private labels, such as private brands, store brands, retailer brands, and wholesale brands (Liljander et al. 2009). One thread of research investigates the relationships between private labels and manufacturer brands, studying issues such as brand preferences and positioning strategies (Choi, Coughlan 
2006). Another thread of research investigates antecedents and consequences of private label customers' behavior, addressing issues such as their attitude toward private labels (Zielke, Dobbelstein 2007).

This study is a study of antecedents of private label customers' behavior. Within this thread of research, three closely related analytical perspectives can be identified: store image (Collins-Dodd, Lindley 2003; Semeijn et al. 2004; Beristain, Zorrilla 2011), private label brand image (Vahie, Paswan 2006), and behavioral intention (Bao et al. 2011; Wu et al. 2011; Diallo 2012). However, there are three knowledge gaps in this body of literature. Firstly, though the perspective of store image is utilized, little attention has been paid to another dimension of store knowledge: store awareness (Hartman, Spiro 2005). Secondly, though the perspectives of store image and private label brand image are utilized, the role of image fit (i.e., the fit between a store and its private label products) cannot be ignored (Bhat, Reddy 2001). Lastly, though the perspective of behavioral intention is utilized, insufficient attention has been paid to repurchase intention and customer lifetime value (CLV) (Rust et al. 2000). Customer lifetime value represents a long-term indicator of a customer's behavior, while behavioral intention tends to be a short-term indicator of a customer's behavior (Kim, Ko 2012). To bridge these three knowledge gaps, this study aims to synthesize the following factors to formulate a model capable of predicting private label customers' behavior: store awareness, store image, private label image, image fit, repurchase intention, and customer lifetime value.

The context of hypermarkets is chosen for examining our model, due to a huge variety of private label products they sell. The remainder of this paper is organized as follows. Section 1 presents literature review and proposes the research hypotheses. Section 2 explains the method utilized to examine the hypotheses, while Section 3 presents the testing results. Section 4 discusses the theoretical and practical implications as well as the limitations of this study.

\section{Literature review and hypothesis development}

\subsection{Store knowledge}

Store knowledge consists of store awareness and store image (Hartman, Spiro 2005: 1112). Store awareness includes store recognition and store recall (Hedhli, Chebat 2009). Store recognition refers to a consumer's ability to identify the store as having been heard previously when given the store name as a cue. Store recall refers to a consumer's ability to retrieve the store name when given cues. Additionally, they suggest that store image refers to a consumer's perception of the attributes associated with a store name. Scholars presented different attributes of store image such as Chowdhury et al. (1998) (i.e., employee service, product quality, atmosphere, convenience, price/value, and product variety) and Hedhli and Chebat (2009) (i.e., appearance, environment, convenience, employees' behavior, service quality, product quality, and price). With regard to store image, service quality, price/value, convenience, and product quality are selected since they represent a typical set of hypermarket attributes (Beristain, Zorrilla 2011). Prior studies have examined the effects of store image on private label perceived quality/quality perception (Bao et al. 2011; Porral, Lang 2015), private label image (Porral, Lang 
2015), brand experience (Dolbec, Chebat 2013), brand attitude (Dolbec, Chebat 2013), and purchase intention (Bao et al. 2011; Porral, Levy-Mangin 2016). However, Hartman and Spiro (2005) propose that store image is a necessary but insufficient construct to understand consumer behavior and store performance and suggest researchers use store knowledge, which includes both store image and store awareness. In contrast to store image, the effect of store awareness on consumer behavior is seldom investigated in the extant literature. Hence, this research seeks to examine the effects of both store image and store awareness on private brand outcomes to fill the knowledge gap.

\subsection{Private label image}

Brand image is treated as an element of brand equity (Keller 1993). Previous studies have comprehended brand image through various angles. Gardner and Levy (1955) suggest that the image of a brand is made up of the ideas, feelings, and attributes a consumer has about a brand. Kim H. B. and Kim W. G. (2005) treat a differentiated image different from other brands as an element of brand image. Inspired by the above studies, this study defines private label image as feelings and beliefs a customer has about a hypermarket private label as well as its differentiated image different from other brands.

Few studies have examined the antecedents and consequences of private label image except Porral and Lang (2015). Porral and Lang (2015) indicated that corporate reputation and store image facilitate private label image and private label image positively influences consumers' purchase intention toward private label products indirectly through private label loyalty. Since Porral and Lang (2015) focused on Spain retailers, more research needs to be conducted in other contexts.

Pina et al. (2010) propose that familiarity with the parent brand has a positive effect on attitude toward the extension simply because of more exposure to the parent brand. This study suggests that store awareness and private label image are similar to familiarity with the parent brand and attitude toward the extension respectively, and higher store awareness leads to a more positive private label image. Thus, the following hypothesis is proposed.

H1: Store awareness has a positive effect on private label image.

Based on cue utilization theory, Collins-Dodd and Lindley (2003) suggest that the store name offers a highly relevant cue for the evaluation of the store brand. They find that customers' perception of store-based value for money and product quality were significantly positively associated with store brand image. Furthermore, Semeijn et al. (2004) propose a direct positive relationship between store service image and customers' attitude toward store branded products. Porral and Lang (2015) indicated that store image fosters private label image. Thus, the following hypotheses are proposed:

H2: Service quality has a positive effect on private label image.

H3: Price/value has a positive effect on private label image.

H4: Convenience has a positive effect on private label image.

H5: Product quality has a positive effect on private label image. 


\subsection{Image fit}

Bhat and Reddy (2001) propose that brand image fit refers to the similarity of brand extension to the specific attributes of the parent brand. This study suggests that stores and private labels are similar to parent brands and their extensions respectively, and defines image fit as the similarity between a store's private label products and the specific attributes of that store.

Past studies investigate the image fit between parent brands and their extensions (Bhat, Reddy 2001; Park et al. 1991), between symbolic brands and their brand extensions (Lau, Phau 2007), between corporate brand and country of origin (Lopez et al. 2011), and between luxury host brand and non-luxury ingredient brand (Moon, Sprott 2016). Relatively few studies examine the image fit between a store and its private label products and this research intends to fill this gap.

Based on cue utilization theory, whether consumers utilize a particular cue as a basis for judging products depends on the predictive value and confidence value of that cue (Richardson et al. 1994). Store image is an extrinsic cue for evaluating store brand products (Richardson et al. 1994). Higher image fit increases the predictive value and confidence value of the cue (i.e., store image) and makes consumers more likely to use store image as a basis for judging private label image. Thus, the following hypotheses are proposed:

H6a: Compared with customers perceiving low image fit, the positive effect of service quality on private label image is stronger for customers perceiving high image fit.

H6b: Compared with customers perceiving low image fit, the positive effect of price/ value on private label image is stronger for customers perceiving high image fit.

H6c: Compared with customers perceiving low image fit, the positive effect of convenience on private label image is stronger for customers perceiving high image fit.

H6d: Compared with customers perceiving low image fit, the positive effect of product quality on private label image is stronger for customers perceiving high image fit.

\subsection{Repurchase intention}

Researchers have defined purchase intention as a customer's estimated likelihood of making a purchase (Miquel-Romero et al. 2014). This study defines repurchase intention as a customer's subjective estimated likelihood that they will continue to purchase a hypermarket's private label products in the future.

Past researches focus on examining purchase intention toward private label products (Bao et al. 2011; Porral, Levy-Mangin 2016). Since acquiring customers is more expensive than retaining current customers (Wood 2004), the role of repurchase intention is more important than purchase intention. Few studies examine how to foster repurchase intention toward private label products and this study attempts to fill this gap.

Pina et al. (2010) propose that familiarity with the parent brand has a positive effect on attitude toward the extension. As store awareness and repurchase intention are similar 
to familiarity with the parent brand and attitude toward the extension respectively, this study contemplates that higher store awareness leads to higher repurchase intention. Thus, the following hypothesis is proposed:

H7: Store awareness has a positive effect on repurchase intention.

According to cue utilization theory, Diallo (2012) suggests that store image provides a highly relevant cue for judging a store brand. Bao et al. (2011) and Wu et al. (2011) find that store image had a positive effect on customers' intention to purchase store brands. Based on the above, this study conjectures that favorable attributes of a store offer positive cues for evaluating its private labels. A more positive store image leads to higher repurchase intention. Thus, the following hypotheses are proposed:

H8: Service quality has a positive effect on repurchase intention.

H9: Price/value has a positive effect on repurchase intention.

H10: Convenience has a positive effect on repurchase intention.

H11: Product quality has a positive effect on repurchase intention.

Wu et al. (2011) propose that the better the private label brand image, the higher customers' private label purchase intention. Porral and Lang (2015) indicate that private label image is highly correlated with private label loyalty. Given the above, favorable attributes of a hypermarket's private label products lead to customers' higher intention to repurchase that hypermarket's private label products. Thus, the following hypothesis is proposed:

H12: Private label image has a positive effect on repurchase intention.

\subsection{Customer lifetime value}

From the perspective of customer lifetime value, Rust et al. (2004: 78) define customer equity as "the sum of the lifetime values of all the firm's current and future customers, where the lifetime value is the discounted profit stream obtained from the customer". In particular, they propose a formula for estimating a customer's lifetime value:

$$
C L V=\sum_{t=0}^{T}\left[(1+d)^{-t} \cdot F_{i t} \cdot S_{i t} \cdot \pi_{i t}\right]
$$

In this formula, $T$ denotes the length of the planning horizon. $t$ denotes time period. $F_{i t}$ denotes the expected frequency of customer $i$ 's purchases in the product category per time period $t$. $S_{i t}$ denotes the expected share of customer $i$ 's wallet for this brand in time $t$. $\pi_{i t}$ denotes the average contribution from a purchase by individual $i$ in time $t$. Lastly, $d$ denotes the discount factor.

Past studies focus on the measurement and applications of customer lifetime value (Chang et al. 2012). Following Rust et al. (2004), some scholars address the measurement of customer lifetime value in specific contexts such as banking industry (Ekinci et al. 2014) and consumer packaged goods industry (Sunder et al. 2016). Past studies have applied customer lifetime value in the contexts of luxury brands (Kim et al. 2012) and Spanish telecommunication services (Segarra-Moliner, Mliner-Tena 2016). To the 
authors' knowledge, customer lifetime value has not been applied in hypermarket private label contexts and this study attempts to fill this gap.

This study views customer lifetime value as a long-term indicator of a customer's behavior, and defines it as a customer's lifetime value concerning purchasing a hypermarket's private label products. Kim and Ko (2012) treat purchase intention and customer equity as a short-term attitudinal variable and a long-term behavioral variable respectively. They find that purchase intention facilitates customer equity. Thus, the following hypothesis is proposed:

H13: Repurchase intention has a positive effect on customer lifetime value.

The research model is illustrated in Figure 1.

\section{Method}

\subsection{Measures}

Store awareness was measured using three items adapted from Hedhli and Chebat (2009). Modified from Chowdhury et al. (1998) and Hedhli and Chebat (2009), four attributes related to store image (i.e., service quality, price/value, convenience, and product quality) were measured using 5, 3, 5, and 4 items, respectively. Private label image was measured using three items developed from Kim H. B. and Kim W. G. (2005). Repurchase intention was measured using three items developed from Wang et al. (2006). Customer lifetime value was measured using five items modified from Hyun (2009). A participant's responses to the five items were further utilized to calculate that participant's customer lifetime value using Rust et al.'s (2000) formula. Lastly, image fit was measured using three items developed from Salinas and Pérez (2009). All items were shown in Appendix.

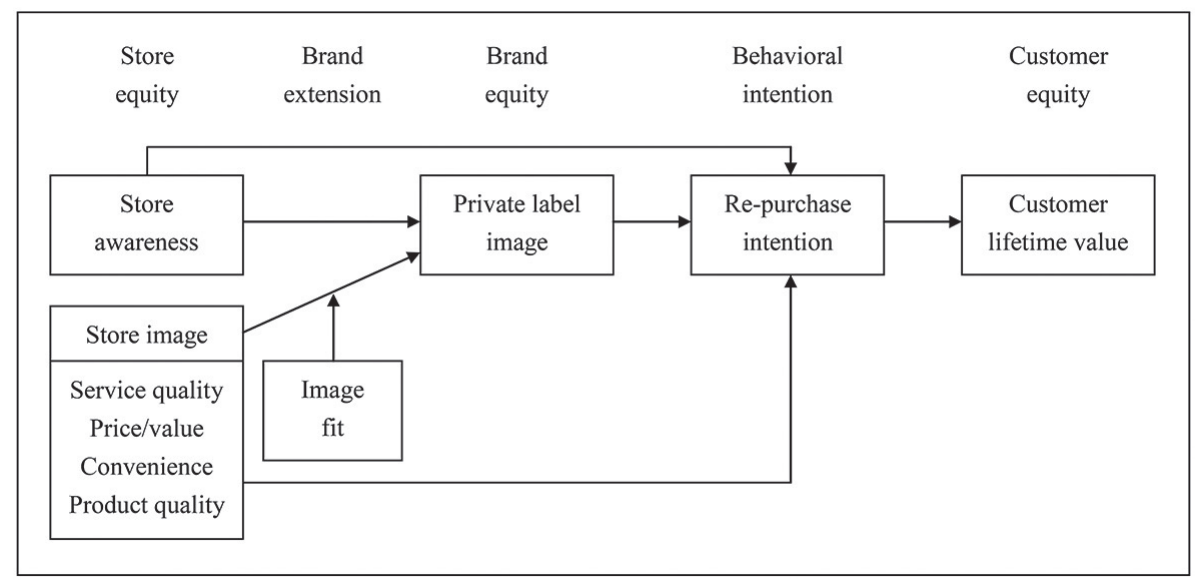

Fig. 1. Research model 


\subsection{Sample}

This study investigated private label products sold by three major hypermarkets in Taiwan: Carrefour, RT-MART, and Far Eastern Géant. They encompassed a variety of product categories, such as foods, beverages, alcohol, electric appliances, and stationery (see Table 1). The research subjects were customers who had ever purchased any products sold under these private labels. Eligible customers were approached via convenience sampling. 110 copies of the survey questionnaires were distributed at each store. A total of 330 questionnaires were distributed, and 275 valid responses were collected, resulting in a valid response rate of $83 \%$. The sample characteristics are indicated in Table 1.

Table 1. Sample characteristics

\begin{tabular}{|c|c|c|c|c|c|}
\hline Characteristics & $\mathrm{N}$ & $\%$ & Characteristics & $\mathrm{N}$ & $\%$ \\
\hline Gender & & & Shopping experience & & \\
\hline Male & 82 & 29.8 & Less than 3 years & 15 & 5.5 \\
\hline Female & 193 & 70.2 & $3 \sim 5$ years & 63 & 22.9 \\
\hline Age & & & $6 \sim 8$ years & 79 & 28.7 \\
\hline Under 24 & 30 & 10.9 & 9 years or more & 118 & 42.9 \\
\hline $25 \sim 30$ & 49 & 17.8 & Average monthly income & & \\
\hline $31 \sim 35$ & 48 & 17.5 & NT $\$ 15,000$ or less & 60 & 21.8 \\
\hline $36 \sim 40$ & 47 & 17.1 & NT\$15,001 30,000 & 71 & 25.8 \\
\hline $41 \sim 45$ & 39 & 14.2 & NT\$30,001 45,000 & 71 & 25.8 \\
\hline $46 \sim 50$ & 41 & 14.9 & NT $\$ 45,001$ or more & 73 & 26.6 \\
\hline Over 51 & 21 & 7.6 & Education level & & \\
\hline Hypermarket & & & Junior high school diploma or lower & 10 & 3.7 \\
\hline Carrefour & 90 & 32.7 & Senior high diploma or equivalent & 54 & 19.6 \\
\hline RT-MART & 90 & 32.7 & Bachelor's or associate's degree & 148 & 53.8 \\
\hline Far Eastern Géant & 95 & 34.6 & Master's degree & 41 & 14.9 \\
\hline Product category & & & $\mathrm{PhD}$ & 22 & 8.0 \\
\hline General food items & 40 & 14.5 & Occupation & & \\
\hline Beverages & 19 & 6.9 & Military or civil servant & 10 & 3.6 \\
\hline Health food & 1 & 0.4 & Student & 58 & 21.1 \\
\hline Alcohol & 1 & 0.4 & Information or communication & 42 & 15.3 \\
\hline Daily items & 175 & 63.6 & Manufacturing & 19 & 6.9 \\
\hline $\begin{array}{l}\text { Electric appliances and } \\
\text { metalware items }\end{array}$ & 9 & 3.3 & Service & 89 & 32.4 \\
\hline Home accessories & 10 & 3.6 & Other & 57 & 20.7 \\
\hline Stationery & 20 & 7.3 & & & \\
\hline
\end{tabular}




\section{Results}

\subsection{Item analysis}

The 29 items measuring store awareness, four attributes related to store image, private label image, repurchase intention, and image fit were analyzed. Three of the five items that measured convenience and one of the four items that measured product quality had a corrected item-total correlation lower than 0.4 (Blunch 2008). Thus, the four items were deleted.

A normality test was conducted on all the remaining items. All the remaining items exhibit significant deviations from normality as indicated by both the KolmogorovSmirnov test ( $\mathrm{p}$-values $<0.001$ ) and Shapiro-Wilk test (p-values < 0.001) (Hair et al. 2016). This suggests that partial least square structural equation modeling as a nonparametric approach is more appropriate than covariance-based structural equation modeling to analyze data (Hair et al. 2016).

\subsection{Outer model}

The outer model and the inner model were analyzed using SmartPLS. Table 2 presented the results of reliability and validity. Service quality, price/value, convenience, product quality, private label image, and repurchase intention had a composite reliability value above 0.6 (Hair et al. 2011). Each indicator's factor loading was higher than 0.4 (Hair et al. 2011). Thus, both internal consistency reliability and indicator reliability were ensured. All 7 constructs had an average variance extracted (AVE) value above 0.5, indicating a sufficient degree of convergent validity (Hair et al. 2011). The AVE value of each latent construct was greater than that latent construct's squared correlations with other latent constructs, and discriminant validity was achieved (Hair et al. 2011).

Table 2. Reliability, convergent validity, and discriminant validity

\begin{tabular}{ccccccccc}
\hline Construct & CR & SA & SQ & PV & CV & PQ & PLI & RI \\
\hline SA & 0.86 & 0.68 & & & & & & \\
\hline SQ & 0.89 & 0.15 & 0.62 & & & & & \\
\hline PV & 0.93 & 0.01 & 0.15 & 0.80 & & & & \\
\hline CV & 0.87 & 0.18 & 0.20 & 0.13 & 0.76 & & & \\
\hline PQ & 0.91 & 0.06 & 0.30 & 0.17 & 0.17 & 0.76 & & \\
\hline PLI & 0.93 & 0.09 & 0.21 & 0.14 & 0.11 & 0.13 & 0.82 & \\
\hline RI & 0.96 & 0.07 & 0.17 & 0.11 & 0.11 & 0.11 & 0.27 & 0.90 \\
\hline
\end{tabular}

Note: Diagonal elements and off-diagonal elements represent average variance extracted and shared variance respectively. Store awareness $=\mathrm{SA}$; Service quality $=\mathrm{SQ}$; Price $/$ value $=\mathrm{PV}$; Convenience $=$ $\mathrm{CV}$; Product quality $=$ PQ; Private label image $=$ PLI; Repurchase intention $=$ RI . 


\subsection{Inner model}

\subsubsection{Direct effects}

Table 3 and Figure 2 presented the empirical results. As for the effect of store knowledge on private label image, store awareness, service quality, and price/value had a significantly positive effect on private label image with estimates of $0.13,0.26$, and 0.21 respectively, suggesting that $\mathrm{H} 1, \mathrm{H} 2$, and $\mathrm{H} 3$ were supported. With regard to the effects of store knowledge on repurchase intention, service quality, price/value, and convenience had a significantly positive effect on repurchase intention with estimates of $0.14,0.08$, and 0.09 respectively, suggesting that $\mathrm{H} 8, \mathrm{H} 9$, and $\mathrm{H} 10$ were supported. Finally, private label image had a significantly positive effect on repurchase intention $(p=0.37)$ and repurchase intention had a significantly positive effect on customer lifetime value ( $p=0.28$ ), suggesting that H12 and H13 were supported.

Table 3. Direct effects, indirect effects, and total effects

\begin{tabular}{|c|c|c|c|c|c|c|c|c|}
\hline & \multicolumn{3}{|c|}{ Direct effects } & \multicolumn{2}{|c|}{ Indirect effects } & \multicolumn{3}{|c|}{ Total effects } \\
\hline & PLI & RI & CLV & RI & CLV & PLI & RI & CLV \\
\hline SA & $0.13^{* *}$ & 0.04 & & $0.05^{* *}$ & 0.02 & $0.13^{* *}$ & 0.09 & 0.02 \\
\hline SQ & $0.26^{* *}$ & $0.14^{* *}$ & & $0.10^{* *}$ & $0.06^{* *}$ & $0.26^{* *}$ & $0.24^{* *}$ & $0.06^{* *}$ \\
\hline $\mathrm{PV}$ & $0.21^{* *}$ & $0.08^{*}$ & & $0.08^{* *}$ & $0.04^{* *}$ & $0.21^{* *}$ & $0.16^{* *}$ & $0.04^{* *}$ \\
\hline $\mathrm{CV}$ & 0.05 & $0.09^{*}$ & & 0.02 & 0.03 & 0.05 & 0.11 & 0.03 \\
\hline PQ & 0.08 & 0.05 & & 0.03 & 0.02 & 0.08 & 0.08 & 0.02 \\
\hline PLI & & $0.37^{* *}$ & & & $0.10^{* *}$ & & $0.37^{* *}$ & $0.10^{* *}$ \\
\hline RI & & & $0.28^{* *}$ & & & & & $0.28^{* *}$ \\
\hline
\end{tabular}

Note: $* * \mathrm{p}<0.05 ; * \mathrm{p}<0.1$; Store awareness $=\mathrm{SA}$; Service quality $=\mathrm{SQ}$; Price/value $=\mathrm{PV}$; Convenience $=\mathrm{CV}$; Product quality $=\mathrm{PQ}$; Private label image $=$ PLI; Repurchase intention $=$ RI. Customer lifetime value $=\mathrm{CLV}$.

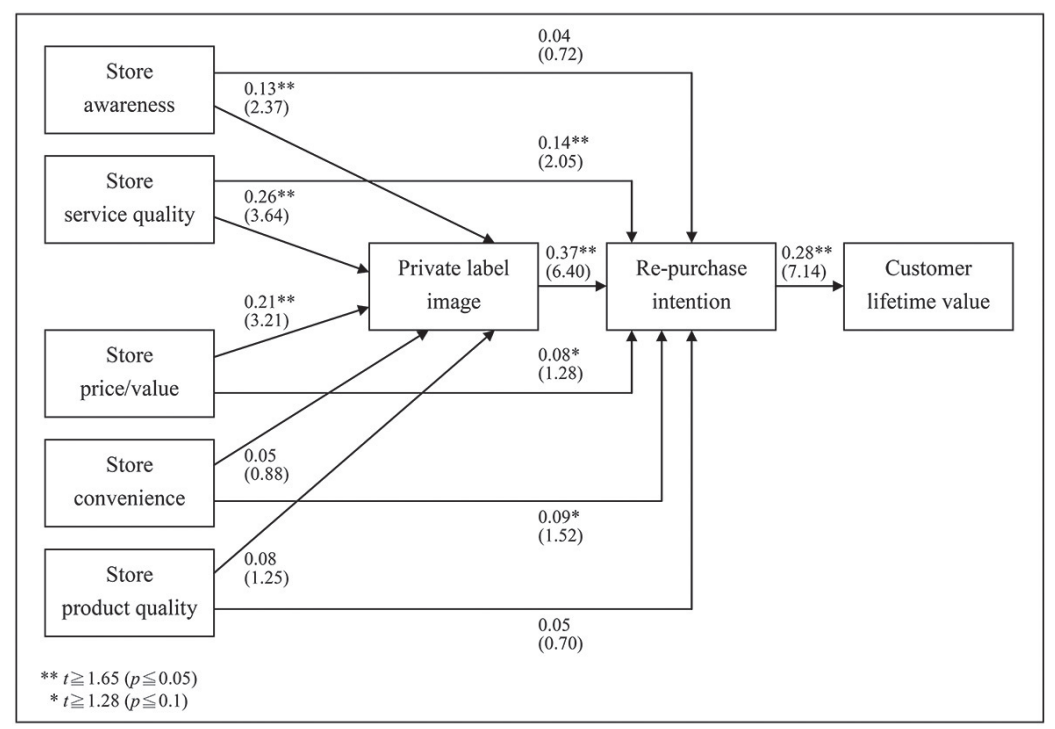

Fig. 2. Path estimate (t-value) 


\subsubsection{Indirect effect}

As previously mentioned, store awareness did not have a significantly positive effect on repurchase intention. However, store awareness had a significantly positive effect on private label image, which also had a significantly positive effect on repurchase intention. This study further calculated the indirect effect of store awareness on repurchase intention via private label image. Table 3 indicates that this significant indirect effect was 0.05 .

\subsection{Moderating effects}

Respondent were classified into high and low image fit groups (median $=4.67 ; N_{\text {high }}=$ 113 and $N_{\text {low }}=162$ ). The independent samples $t$-test found that the two groups were significantly different $(t=17.82, p<0.001)$. The multi-group analysis with $t$-test approach was conducted for moderation hypotheses (Chin 1998). The results of parameter comparison revealed that significant group difference were found in the relationships between private label image and service quality, between private label image and price/ value, and between private label image and convenience. A further look into the three significant relationships showed that only the estimates of two groups were as expected in the price/value case $\left(p_{\text {high }}=0.23, p_{\text {low }}=0.14, t=1.64\right)$, and H6b was supported. In the cases of service quality, the path estimate of low image fit group was higher than that of high group ( $p_{\text {high }}=0.13, p_{\text {low }}=0.20, t=1.30$ ), and H6a was not supported. In the cases of convenience, the path estimate of low image fit group was unexpectedly negative $\left(p_{\text {high }}=0.26, p_{\text {low }}=-0.03, t=5.68\right)$, and H6c was not supported.

\section{Discussion}

\subsection{Theoretical implications}

Four theoretical implications are found from our results. First, store awareness constituted a factor positively influencing private label image. This finding extended the study of Pina et al. (2010). As for the four attributes of store image, service quality constituted a factor positively influencing private label image, and this effect is only significant in the low image fit group. This finding elaborated the study of Semeijn et al. (2004). Price/value constituted a factor positively influencing private label image. In particular, compared with customers perceiving low image fit, the positive effect of price/value on private label image was stronger for customers perceiving high image fit. This finding elaborated Collins-Dodd and Lindley's (2003) study and Vahie and Paswan's (2006) study. Convenience constituted a factor positively influencing private label image only in the high image fit group. This finding elaborated Vahie and Paswan's (2006) study. Product quality did not constitute a factor positively influencing private label image. This finding was dissimilar to Vahie and Paswan's (2006) study. A possible explanation is that most of products sold in a hypermarket may be products of manufacturer brands. Customers' perception of product quality may mostly build upon their impression of these products. As a result, product quality may not be capable of predicting private label image. 
Second, store awareness did not directly influence repurchase intention, but it did have an indirect effect on repurchase intention through private label image. This new finding extended the study of Pina et al. (2010). The explanation is that, in the repurchase situation, customers had real experiences of purchasing a hypermarket's private label products, forming their private label image. It was their private label image that influences their repurchase intention, rather than the exposure effects of store awareness. As for the four attributes of store image, service quality constituted a factor positively influencing repurchase intention. This new finding was similar to the study of Bao et al. (2011), but it was dissimilar to Diallo's (2012) study. Price/value constituted a factor positively influencing repurchase intention. This new finding was similar to previous studies (Bao et al. 2011; Wu et al. 2011). Convenience constituted a factor positively influencing repurchase intention. This new finding was similar to the study of Bao et al. (2011). However, product quality did not constitute a factor positively influencing repurchase intention. This new finding was similar to the study of Diallo (2012), but it was dissimilar to other studies (Bao et al. 2011; Wu et al. 2011). Product quality may not be capable of predicting their private label product repurchase intention because customers' perception of product quality may mostly build upon their impression of manufacturer brand products.

Thirdly, private label image constituted a factor positively influencing repurchase intention. This new finding was similar to Diallo's (2012) study, but it was dissimilar to the study of Wu et al. (2011). Repurchase intention constituted a factor positively influencing customer lifetime value. This new finding was similar to Kim and Ko's (2012) study.

Fourthly, this research empirically tests cue utilization theory in the hypermarket context and further indicated that the image fit between a store and its private label products is one boundary condition of the theory. Past studies revealed that consumers use store image as an extrinsic cue for evaluating store brand products (Bao et al. 2011; Porral, Lang 2015). The results of this research support their findings and further indicate the moderating role of image fit. Consumers utilize store image to judge private label image considering different levels of image fit.

\subsection{Practical implications}

Hypermarkets can strengthen customers' repurchase intention for private label products by improving service quality, price/value, convenience, and store awareness. As for service quality, hypermarkets are advised to train their service personnel to have service competence such as being familiar with product information and being friendly to customers. Technological systems such as point of sale systems need to be designed to meet customer service needs. With regard to price/value, honest pricing techniques (e.g., unit pricing) would be helpful in facilitating customers' positive evaluation of price/value. As far as store convenience is concerned, larger product assortments may be useful in facilitating customers' positive evaluation of store convenience. Since store awareness indirectly influences repurchase intention through private label image, hypermarkets can expand advertising investments that increase the frequency and the scope of brand appearance. Lastly, to facilitate the positive outcomes for private label products, 
practitioners can decide on the level of image fit between a store and its private label products based on the type of store image that the store possesses. Specifically, when store image carries much weight on service quality associations, a store can launch private label products with low image fit. Conversely, private label products with high image fit should be launched when store image consists of mostly convenience associations or price/value associations.

\subsection{Limitations and future avenues}

Several study limitations must be noticed and future studies are suggested based on these limitations. First, the socio-cultural context researched in this study was confined to Taiwan, and Carrefour, RT-MART, and Far Eastern Géant were the target retailers. Future research is encouraged to examine the research model with data from different societies, cultures, and hypermarkets to increase the external validity of our research model. Second, participants in this study were approached via convenience sampling, and future studies are encouraged to adopt probability sampling, making their model evaluation grounded in the strict statistical foundation. Third, this research is cross-sectional, all the statistically supported relationships are regarded as associational. Future studies can use experimental design to test the proposed model.

\section{Conclusions}

This study developed a model to predict customer lifetime value for hypermarket private label products. Three findings were revealed. First, store image variables (except product quality) and store awareness affect repurchase intention directly or indirectly through private label image. Second, image fit moderates the relationships between store image variables (except product quality) and private label image. Third, private label image positively influences customer lifetime value. By synthesizing research on store knowledge, brand extension, behavioral intention, and customer equity, this study contributed to better understanding of antecedents of private label customers' behavior.

\section{References}

Bao, Y.; Bao, Y.; Sheng, S. 2011. Motivating purchase of private brands: effects of store image, product signatureness, and quality variation, Journal of Business Research 64(2): 220-226. https://doi.org/10.1016/j.jbusres.2010.02.007

Beristain, J. J.; Zorrilla, P. 2011. The relationship between store image and store brand equity: a conceptual framework and evidence from hypermarkets, Journal of Retailing and Consumer Services 18(6): 562-574. https://doi.org/10.1016/j.jretconser.2011.08.005

Bhat, S.; Reddy, S. K. 2001. The impact of parent brand attribute associations and affect on brand extension evaluation, Journal of Business Research 53(3): 111-122.

https://doi.org/10.1016/S0148-2963(99)00115-0

Blunch, N. J. 2008. Introduction to structural equation modelling: using SPSS and AMOS. London, England: Sage. https://doi.org/10.4135/9781446249345

Bodur, H. O.; Tofighi, M.; Grohmann, B. 2016. When should private label brands endorse ethical attributes?, Journal of Retailing 92(2): 204-217. https://doi.org/10.1016/j.jretai.2015.11.001 
Chang, W.; Chang, C.; Li, Q. 2012. Customer lifetime value: a review, Social Behavior and Personality: An International Journal 40(7): 1057-1064. https://doi.org/10.2224/sbp.2012.40.7.1057

Chin, W. W. 1998. The partial least squares approach for structural equation modeling, Chapter 10 in G. A. Marcoulides (Eds.). Modern methods for business research. Mahwah, NJ: Lawrence Erlbaum Associates.

Choi, S. C.; Coughlan, A. T. 2006. Private label positioning: quality versus feature differentiation from the national brand, Journal of Retailing 82(2): 79-93.

https://doi.org/10.1016/j.jretai.2006.02.005

Chowdhury, J.; Reardon, J.; Srivastava, R. 1998. Alternative modes of measuring store image: an empirical assessment of structured versus unstructured measures, Journal of Marketing Theory and Practice 6(2): 72-86. https://doi.org/10.1080/10696679.1998.11501797

Collins-Dodd, C.; Lindley, T. 2003. Store brand and retail differentiation: the influence of store image and store brand attitude on store own brand perceptions, Journal of Retailing and Consumer Services 10(6): 345-352. https://doi.org/10.1016/S0969-6989(02)00054-1

Diallo, M. F. 2012. Effects of store image and store brand price-image on store brand purchase intention: application to an emerging market, Journal of Retailing and Consumer Services 19(3): 360-367. https://doi.org/10.1016/j.jretconser.2012.03.010

Dolbec, P. Y.; Chebat, J. C. 2013. The impact of a flagship vs. a brand store on brand attitude, brand attachment and brand equity, Journal of Retailing 89(4): 460-466.

https://doi.org/10.1016/j.jretai.2013.06.003

Ekinci, Y.; Uray, N.; Ülengin, F. 2014. A customer lifetime value model for the banking industry: a guide to marketing actions, European Journal of Marketing 48(3/4): 761-784.

https://doi.org/10.1108/EJM-12-2011-0714

Gardner, B. B.; Levy, S. J. 1955. The product and the brand, Harvard Business Review 33(2): 33-39.

Hair, Jr. J. F.; Hult, G. T. M.; Ringle, C.; Sarstedt, M. 2016. A primer on partial least squares structural equation modeling (PLS-SEM). $2^{\text {nd }}$ ed. Los Angels: Sage Publications.

Hair, J. F.; Ringle, C. M.; Sarstedt, M. 2011. PLS-SEM: indeed a silver bullet, Journal of Marketing Theory and Practice 19(2): 139-151. https://doi.org/10.2753/MTP1069-6679190202

Hartman, K. B.; Spiro, R. L. 2005. Recapturing store image in customer-based store equity: a construct conceptualization, Journal of Business Research 58(8): 1112-1120.

https://doi.org/10.1016/j.jbusres.2004.01.008

Hedhli, K. E.; Chebat, J. C. 2009. Developing and validating a psychometric shopper-based mall equity measure, Journal of Business Research 62(6): 581-587.

https://doi.org/10.1016/j.jbusres.2008.05.016

Hyun, S. S. 2009. Creating a model of customer equity for chain restaurant brand formation, International Journal of Hospitality Management 28(4): 529-539.

https://doi.org/10.1016/j.ijhm.2009.02.006

Keller, K. L. 1993. Conceptualizing, measuring, and managing customer-based brand equity, Journal of Marketing 57(1): 1-22. https://doi.org/10.2307/1252054

Kim, A. J.; Ko, E. 2012. Do social media marketing activities enhance customer equity? An empirical study of luxury fashion brand, Journal of Business Research 65(10): 1480-1486.

https://doi.org/10.1016/j.jbusres.2011.10.014

Kim, H. B.; Kim, W. G. 2005. The relationship between brand equity and firms' performance in luxury hotels and chain restaurants, Tourism Management 26(4): 549-560.

https://doi.org/10.1016/j.tourman.2004.03.010 
Kim, K. H.; Ko, E.; Xu, B.; Han, Y. 2012. Increasing customer equity of luxury fashion brands through nurturing consumer attitude, Journal of Business Research 65(10): 1495-1499. https://doi.org/10.1016/j.jbusres.2011.10.016

Lau, K. C.; Phau, I. 2007. Extending symbolic brands using their personality: examining antecedents and implications towards brand image fit and brand dilution, Psychology \& Marketing 24(5): 421-444. https://doi.org/10.1002/mar.20167

Liljander, V.; Polsa, P.; van Riel, A. 2009. Modelling consumer responses to an apparel store brand: store image as a risk reducer, Journal of Retailing and Consumer Services 16(4): 281-290. https://doi.org/10.1016/j.jretconser.2009.02.005

Lopez, C.; Gotsi, M.; Andriopoulos, C. 2011. Conceptualising the influence of corporate image on country image, European Journal of Marketing 45(11/12): 1601-1641.

https://doi.org/10.1108/03090561111167315

Miquel-Romero, M. J.; Caplliure-Giner, E. M.; Adame-Sánchez, C. 2014. Relationship marketing management: its importance in private label extension, Journal of Business Research 67(5): 667-672. https://doi.org/10.1016/j.jbusres.2013.11.025

Moon, H.; Sprott, D. E. 2016. Ingredient branding for a luxury brand: the role of brand and product fit, Journal of Business Research 69(12): 5768-5774.

https://doi.org/10.1016/j.jbusres.2016.04.173

Park, C. W.; Milberg, S. J.; Lawson, R. 1991. Evaluation of brand extensions: the role of product feature similarity and brand concept consistency, Journal of Consumer Research 18(2): 185-193. https://doi.org/10.1086/209251

Pina, J. M.; Iversen, N. M.; Martinez, E. 2010. Feedback effects of brand extensions on the brand image of global brands: a comparison between Spain and Norway, Journal of Marketing Management 26(9/10): 943-966. https://doi.org/10.1080/02672570903458789

Porral, C. C.; Lang, M. F. 2015. Private labels: the role of manufacturer identification, brand loyalty and image on purchase intention, British Food Journal 117(2): 506-522.

https://doi.org/10.1108/BFJ-06-2014-0216

Porral, C. C.; Levy-Mangin, J. P. 2016. Food private label brands: the role of consumer trust on loyalty and purchase intention, British Food Journal 118(3): 679-696.

https://doi.org/10.1108/BFJ-08-2015-0299

Richardson, P. S.; Dick, A. S.; Jain, A. K. 1994. Extrinsic and intrinsic cue effects on perceptions of store brand quality, Journal of Marketing 58(4): 28-36. https://doi.org/10.2307/1251914

Rust, R. T.; Ambler, T.; Carpenter, G. S.; Kumar, V.; Srivastava, R. K. 2004. Measuring marketing productivity: current knowledge and future directions, Journal of Marketing 68(4): 76-89. https://doi.org/10.1509/jmkg.68.4.76.42721

Rust, R. T.; Zeithaml, V. A.; Lemon, K. N. 2000. Driving customer equity: how customer lifetime value is reshaping corporate strategy. New York, NY: The Free Press.

Salinas, E. M.; Pérez, J. M. P. 2009. Modeling the brand extensions' influence on brand image, Journal of Business Research 62(1): 50-60. https://doi.org/10.1016/j.jbusres.2008.01.006

Segarra-Moliner, J. R.; Moliner-Tena, M. Á. 2016. Customer equity and CLV in Spanish telecommunication services, Journal of Business Research 69(10): 4694-4705.

https://doi.org/10.1016/j.jbusres.2016.04.017

Semeijn, J.; van Riel, A. C. R.; Ambrosini, A. B. 2004. Consumer evaluations of store brands: effects of store image and product attributes, Journal of Retailing and Consumer Services 11(4): 247-258. https://doi.org/10.1016/S0969-6989(03)00051-1

Sunder, S.; Kumar, V.; Zhao, Y. 2016. Measuring the lifetime value of a customer in the consumer packaged goods industry, Journal of Marketing Research 53(6): 901-921.

https://doi.org/10.1509/jmr.14.0641 
Vahie, A.; Paswan, A. 2006. Private label brand image: its relationship with store image and national brand, Journal of Retail and Distribution Management 34(1): 67-84.

https://doi.org/10.1108/09590550610642828

Wang, Y. S.; Lin, H. H.; Luarn, P. 2006. Predicting consumer intention to use mobile service, Information Systems Journal 16(2): 157-179. https://doi.org/10.1111/j.1365-2575.2006.00213.x

Wood, L. 2004. Dimensions of brand purchasing behaviour: consumers in the 18-24 age group, Journal of Consumer Behaviour 4(1): 9-24. https://doi.org/10.1002/cb.154

Wu, P. C. S.; Yeh, G. Y. Y.; Hsiao, C. R. 2011. The effect of store image and service quality on brand image and purchase intention for private label brands, Australasian Marketing Journal 19(1): 30-39. https://doi.org/10.1016/j.ausmj.2010.11.001

Zielke, S.; Dobbelstein, T. 2007. Customers willingness to purchase new store brands, Journal of Product and Brand Management 16(2): 112-121. https://doi.org/10.1108/10610420710739982

\section{APPENDIX}

\section{Store awareness}

1. Hypermarket $\mathrm{X}$ is well-known.

2. You can clearly identify Hypermarket $X$ among other hypermarkets.

3. You can quickly identify some of the characteristics of Hypermarket X.

\section{Service quality}

1. Hypermarket $\mathrm{X}$ has good services.

2. The service personnel in Hypermarket $X$ are friendly.

3. The service personnel in Hypermarket $X$ can help you or answer your questions.

4. The employees of Hypermarket $X$ are honest to customers.

5. You like the services offered by Hypermarket X.

\section{Price/value}

1. The products sold in Hypermarket $\mathrm{X}$ are reasonably priced.

2. The products sold in Hypermarket $X$ are worth buying.

3. You can buy cheaper products at Hypermarket X.

\section{Convenience}

1. Parking is convenient in Hypermarket $X^{*}$.

2. It is convenient for you to visit Hypermarket $X^{*}$.

3. The products sold in Hypermarket $X$ can better satisfy your needs.

4. It is easy for you to search for needed products in Hypermarket X.

5. The opening hours of Hypermarket X make shopping convenient to you*.

\section{Product quality}

1. The products sold by Hypermarket $\mathrm{X}$ have good quality.

2. You like the products sold by Hypermarket X.

3. Hypermarket $\mathrm{X}$ offers a wide range of products across numerous categories*.

4. I feel assured of the quality of the products sold by Hypermarket X. 


\section{Private label image}

1. Product $Y$ sold by Hypermarket $X$ has a better image than other brands.

2. You believe in Product Y sold by Hypermarket X.

3. You feel satisfied with Product Y sold by Hypermarket X.

\section{Repurchase intention}

1. You are willing to continue to buy Product Y sold by Hypermarket X.

2. You will continue to buy Product $Y$ sold by Hypermarket $X$ in the future.

3. You are willing to increase your purchase of Product Y sold by Hypermarket $\mathrm{X}$ in the future.

\section{Customer lifetime value}

1. How many times do you buy private label products at Hypermarket X per month?

2. How much do you spend each time on average when you visit Hypermarket $X$ ?

3. The next time you shop, what is the probability that you will visit Hypermarket $\mathrm{X}$ ?

4. Compared with other manufacturer brands, how much of discount rate do the private label products of Hypermarket X usually offer? (e.g., 5\% means 5\% cheaper than the products of other manufacturer brands)

5. How many years, in your lifetime, would you expect that you will continue going to Hypermarket X?

\section{Image fit}

1. You agree that Product $Y$ fits the image of Hypermarket $X$.

2. You agree that Product Y logically conforms to the image of Hypermarket X.

3. You agree that Product $Y$ is consistent with the image of Hypermarket X.

Note. * item deleted.

Hsin-Hui LIN is a Professor in the Department of Distribution Management at National Taichung University of Science and Technology, Taiwan. She received her PhD in Business Administration from National Taiwan University of Science and Technology. Her current research interests include electronic commerce, service marketing, and customer relationship management. Her work has been published in academic journals such as Academy of Management Learning and Education, Information Systems Journal, Information \& Management, International Journal of Information Management, British Journal of Educational Technology, among others.

Hsien-Ta LI is an Assistant Professor in the Department of Business Administration at National Cheng Kung University, Taiwan. He received his PhD in Management from University of Edinburgh, UK. He was a post-doctoral fellow in the Department of Information Management at National Changhua University of Education, Taiwan. His work has been published in Tourism Management, Thinking Skills and Creativity, Online Information Review, and Journal of Journal of Global Information Management. 
Yi-Shun WANG is a Distinguished Professo in the Department of Information Management at the National Changhua University of Education, Taiwan. He received his PhD in MIS from National Chengchi University, Taiwan. His current research interests include IS success models, management education, customer relationship management, knowledge management, IT/IS adoption strategies, and e-learning. He has published papers in journals such as Academy of Management Learning and Education, Information Systems Journal, Information \& Management, International Journal of Information Management, Computers \& Education, British Journal of Educational Technology, among others.

Timmy H. TSENG is a post-doctoral fellow in the Department of Information Management at National Changhua University of Education, Taiwan. He received his $\mathrm{PhD}$ in Marketing from National Chengchi University, Taiwan. His current research interests include experiential marketing, e-marketing, and service marketing. His work has been published in Computers in Human Behavior, European Journal of Marketing, and Internet Research.

Ya-Ling KAO was a post-doctoral fellow in the Department of Distribution Management at National Taichung University of Science and Technology, Taiwan. She received her PhD in Transportation and Communication Management Science from National Cheng Kung University, Taiwan. Her work has been published in Tourism Management and Service Industries Journal.

Min-Yi WU received his Master of Business Administration in Distribution Management from National Taichung University of Science and Technology, Taiwan. His research interests include customer relationship management and brand management. 